\title{
THE CAESAR LAW FOR THE PROTECTION OF CIVILIANS IN SYRIA: OBJECTIVES AND RAMIFICATIONS
}

\author{
Dr. SL. Ali MADOUNI (i) $1 *$ \\ Hichem DERRADJI, PhD. C. (iD) 2 \\ 1 University of Biskra-Algeria Department of Political Science, ali.madouni@univ-biskra.dz, *Correspondent Author \\ 2 University of Msila - Algeria, Department of Political Science, hichem.derradji@univ-msila.dz
}

\begin{tabular}{|c|c|}
\hline Article history: & A b s t r a c t \\
\hline Submission 20 August 2020 & This research aims to demonstrate Caesar's law to protect civilians in Syria and its effect on the social \\
\hline Accepted 30 November 2020 & and economic circumstances of millions of Syrians stuck in their country because of the state of the \\
\hline Available online 31 December 2020 & siege imposed by the law's sanctions. The question tries to focus on how the law can achieve its \\
\hline Keywords: & human aims under the negative economic consequences it has on civilians, relying on the new \\
\hline Caesar Law, & political economy approach. It tried to interpret the non-economic activity of politicians under the \\
\hline The Syrian Regime, & Economy cover. Accordingly, The United States continues to tighten its hold on the Syrian system \\
\hline Sanctions, & to exercise pressure on Syria, and to make political compromises and start significant political \\
\hline United States of America., & reforms immediately. Still, the direct targeting of Syrian economic structures through the law- \\
\hline & imposed blockade has isolated the Syrian regime and cut off all official economic ties externally. It \\
\hline & is encouraging the escalation of dealings with informal mediators, which has led to a sharp collapse \\
\hline & in the Syrian Lira and a significant increase in consumer prices, which has been reflected negatively \\
\hline & the social reality in the light of the marked increase in poverty rates. \\
\hline
\end{tabular}

\section{Introduction}

After the local economy's catastrophic failure, the Syrian crisis made its first decade. Ten consecutive years of warfare have triggered structural changes in the Syrian economy structure that have evolved and exacerbated the trouble of becoming one of the world's largest war economies. However, the last year has affected this collapsed economy more than the number of ramifications left by the consequences of the Corona pandemic, the sanctions imposed by the USA administration on the Syrian regime, or what is known as the Convention of Caesar's Act. On June 17, 2020, the Caesar Civil Security Act formally entered Syria and added a new collection of U.S. sanctions against the Syrian regime. Additionally, to many Syrian and overseas persons and institutions selling Syrian goods, supplies or military equipment, or even those trying to work in the country's reconstruction.

The U.S. Administration chose to name Caesar regarding the dissident Syrian military photographer who revealed more than 55,000 photos from inside the regime's prisons. Thus, it draws one of the most critical chapters of documenting the regime's crimes in Syria.

This Act tries to protect civilians from the effects of the conflict in Syria. It contributes theoretically to hunger due to its adverse economic impact, especially after the regime resorted to the use of mediators and commercial brokers to make different supply deals. Effectively, it means the rise of prices, the persistence of the Syrian Lira depreciation, and the increase of poverty rates. It is seen as a problem that the Act establishes a kind of fear at the international level in dealing with any Syrian side, even if it is not a governmental part. In this case, the indirect effect is more severe than the direct impact itself; furthermore, there are other risks addressed by law in the issues of reconstruction and engineering, which means targeting any future attempts to rebuild what the war has destroyed. The Act also pushed foreign insurance or transport companies operating in Syria to deal with the Government through mediators and brokers indirectly, which are reflected negatively on the population (Nasr, 2020). 
Amid this controversy, this paper focuses on the following problem: How can the Caesar Act protect the civilians in Syria achieve its humanitarian objectives in the light of the negative economic repercussions that it has on the Syrian people? This approach investigates the feasibility of the Act that got here to defend civilians simultaneously, as its effects are reflected negatively on the Syrian people's financial and social situation.

\section{Methodology}

Theoretically, this paper is based mainly on the entry point of the new political economy, where the entry points out that: " analysis examines the possible linkages between politics and economics based on theories of economics, law, and political and social sciences" (Development, 2008).

The new political economy is essentially the theoretical approach developed by economists, encompassing social choice views. It has proved to be a real foundation for understanding the neoclassical economists' and political scientists' economically irrational policies. In doing so, he presents a practical theory to respond to Robert Bates' difficult question: "Why should rational men adopt public policies that have severe consequences for the societies they govern? The new political economy seeks to understand the non-economic market for political activity, using the analytical language and tools of economists, and in this context, it examines the State; to explain the decision-making of political and bureaucratic elites" (Grindle, 1989).

The new political economy is an essential theoretical input used to clarify the relationship between the political-economic sanctions with the Caesar Act and those sanctions' economic and social implications. Both do not recognize the fate of the millions of Syrians who have been driven into extremes by the ruling political classes in the United States of America and Syria.

\section{Results and Figures}

The Caesar Law for the Protection of Civilian Persons in Syria opens an extensive debate approximately its targets and its capacity to obtain them on the only hand. Its harmful effects on civilians, on the alternative hand, so it could be beneficial to examine the regulation and try and find out the maximum critical bad results it has delivered at the Syrian people. Additionally, seeing the highest vital viable eventualities in their punishments are roughly the fate.

\subsection{Reading on the Law}

According to the U.S. official version, the Caesar Act aims at depriving Syrian President Bashar El-Assad of any chance to turn his military victory on the ground into a political gain through which he devotes his chances of remaining in power indefinitely.
The penalties provided for by the Act target entities working for Assad in four sectors: Oil and natural gas, the aeronautics industry, construction, and engineering, which include direct and oblique guide for the regime, including help for militias sponsored with the aid of using Iran and Russia working in Syria. The penalties are both global and local activities that comply with the Assad system, keeping it from exceeding such liabilities by circumventing them.

Any economic activity will also automatically be prolonged, as will any dealings with Iran and any regional and international actors if they consider investing or working in Syria (Al Shami, 2020).

This means that the Caesar Act, unlike previous sanctions, puts under its authority actors from other institutions and countries involved in such activities, including cross-border business networks deemed necessary for the regime's survival. The most vulnerable are Hezbollah in Lebanon, in particular, and the Assad regime's allies in Russia, China, and Iran (Heydemann, 2020).

The penalties for the Caesar Act entered into force on Wednesday, June 17, 2020. The same day, the State Department and the Treasury Department observed joint action leading to 39 persons and organizations' appointment under direct sanctions. Of these 39 targets, the foreign ministry has set 15 targets under Executive Order No. 13,894, including the renaming of Bashar El-Assad, Iran's militia, General Fatimid, and Bashar al-Assad's wife, Asmaa El-Assad, and the fourth division of the Syrian Arab Army. The Treasury has identified 24 other targets under Executive order 13573 that target institutions as owned or controlled by the Syrian Government, and by Executive order 13582 for foreign institutions providing material assistance or support to the Government in Syria (Caroline E. Brown, 2020).

The U.S. bill attempts to focus on economic sanctions which primarily affect the measures related to the Central Bank of Syria, where all reporting problems have been resolved in terms of the time it takes to issue the report, its form as described in the third item of Article I, and the identification of appropriate congressional committees for supervision, which are listed as follows: The Foreign Affairs Committee, the Financial Services Committee, the House appropriations committee, the Foreign Relations Committee, the Banking, Housing, and Urban Affairs Committee, and the Senate Appropriations Committee (Caesar Syria Civilian Protection Act of 2019).

To extend, focusing on sanctions relating to foreign persons engaged in specific transactions, where sanctions are generally imposed on any unfamiliar person if the President decides to 
engage with knowledge in one of the following expressed activities: (Caesar Syria Civilian Protection Act of 2019).

- Caught Providing financial, material or technical support, engaging in a significant deal with the Syrian Government or any other foreign person, whether a military contractor, mercenary, paramilitary force, acting intentionally in an army capacity inside Syria for or on behalf of the Syrian Government, the Government of the Russian Federation or the Government of Iran; Or any sanctioned foreign person with Syria.

- $\quad$ involved in selling or supplying essential goods, services, technology, information, support, or other support dramatically. Facilitates maintenance or extension of the Syrian State's domestic natural gas, petroleum or petroleum products Selling or intended provision of aircraft spares or spare parts for military purposes in Syria for or on behalf of the Syrian Government to any foreign person operating in an area under the direct or indirect control of the Syrian Government or foreign forces associated with the Syrian Government.

- to provide knowingly any essential goods or services associated with the operation of aircraft used for military purposes in Syria.

- Provision- directly or indirectly- of significant construction or engineering services to the Syrian Government.

The penalties insert anyone realized to be involved in such defined operations encompass the withholding of assets. The President sports all powers below the International Economic Emergency Law to withhold assets inside the United States of America, further stopping him from getting into American soil. It is inadmissible for obtaining, ineligible for, or now no longer accepting or returning the visa to the United States, with all legitimate access cancelled, with positive exceptions to the United Nations Headquarters Agreement (Caesar Syria Civilian Protection Act of 2019).

Humanitarian figures or institutions have been excluded from any follow-up, prosecutions, or sanctions if they are active in Syria. This "humanitarian exclusion," reflecting similar humanitarian exceptions in both U.S. and European sanctions against Syria, aims to ensure the flow of humanitarian and medical assistance needed to Syria and mitigate the unintended economic consequences of sanctions on the Syrian people (SJAC, 2020).

The U.S. Secretary of State Michael Pompeo issued a press statement, in which; he spoke about his country's commitment toward humanitarian aids, expressing that Caesar's law was not targeted at it when he said: "The United States remains committed to working with the United Nations and international partners to provide life-saving assistance to the Syrian people, who are still suffering at the hands of the Assad A press release was released by U.S. Secretary of State Michael Pompeo, in which he spoke of his country's dedication to humanitarian aid, claiming that Caesar 's law was not targeted when he said: "The United States remains committed to working with the United Nations and international partners to provide life-saving assistance to the Syrian people who are still suffering at the hands of the United Nations and international partners.". We are the largest single humanitarian donor to the Syrian people. Since the beginning of the conflict, we have provided more than $\$ 10.6$ billion dollars in humanitarian aid and more than $\$ 1.6$ billion dollars in non-humanitarian and stability assistance throughout Syria, even in areas under Assad's control. The Caesar Law and other U.S. sanctions on Syria do not target humanitarian aid to the Syrian people or hamper our activities to stabilize northeast Syria. We will continue our humanitarian assistance through our various international and Syrian partners, even in areas under the control of the regime" (Pompeo, 2020).

Article 302 of the Act also permits certain waivers and exemptions, especially those related to activities and transactions subject to reporting requirements under the National Security Act 1947. Alternatively, any transaction necessary to comply with the United States' obligations under the United Nations Headquarters Agreement, the Consular Relations Agreement, or any other international agreement to which the United States is a part. (Caesar Syria Civilian Protection Act of 2019)

\subsection{Consequences of the Law}

Many observers believe that the Caesar Law for the Protection of Civilians in Syria has made a negative contribution to the country's social and economic life and has driven many Syrians into extreme poverty, especially from the middle and low classes. The law contributed directly to Syria's currency crisis as fears of its economic repercussions increased.

Actually, throughout the past crisis years, the Syrian economy has relied on the Lebanese banking sector, where it is the gateway to the Syrian economy to the external world. Lebanon is the place where Syrian business people and individuals have deposited their savings and bought dollars. At the same time, its banks issued letters of credit and other payment facilities required by Syrian merchants to import goods into their domestic markets. The U.S. currency jumped into the Lebanese foreign exchange market, followed by the Syrian money, as soon as Lebanese banks started to limit dollar sales in August 2019-also, preventing depositors from making their savings in that currency. With the collapse of the Lebanese Lira, the Syrian Lira also retreated. At 
the end of July 2019, the dollar cost was 606 Syrian pounds on the black market. It reached 635 Syrian lire at the end of August and rose steadily to 1,040 Syrian lire at the end of January 2020 (Yazigi, 2020).

Abu Hassan from Homs, who works in the Ministry of Oil, said that he was suffering after the decrease in Lira's price, adding that I pay about 60 thousand Syrian liras (27 dollars). That is now enough for only four meals for my family of seven. Fear of starving my kids forced me to sell a piece of land I had for ten years. I consider myself lucky because I had something to sell, and at the same time, there are people who cannot even buy breadcrumbs and have nothing to sell. Even this piece of land gave me enough money for just three months, and then I have no idea how to manage to feed my children (Qussai Jukhadar, 2020).

Figure 1. The price of the U.S. dollar in the Syrian black market (in SYP)

July 2019 - February 2020

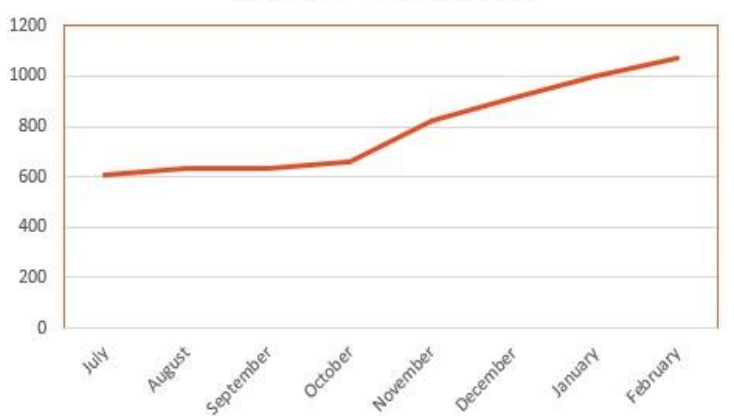

Source: Jihad Yazigi. (March 2020). Syria's Growing Economic

Woes: Lebanon's Crisis, the Caesar Act and Now the

Coronavirus. Arab Reform Initiative. P 3.

As the price of the Syrian Lira continues to fall into the market, the social and economic conditions of millions of Syrians stranded in their country will deteriorate further, and the increasing role of brokers and brokers after the official international authorities' fear dealing with the Syrian regime. These brokers and intermediaries maximize the benefit that Syrian citizens are forced to bear.

The Caesar Act additionally explicitly targets "Syria's local manufacturing of natural gas, petroleum or petroleum products," and any individual or entity "intentionally, directly or indirectly, presents vital production or engineering offerings to the Syrian Government.

"In practical terms, these new restrictions target the entire Syrian economy and reconstruction efforts" (Charles A. Sills, 2020). therefore, the Caesar Act is an additional deterrent to any interest in the Syrian economy by foreign companies and institutions, thus eliminating the limited possibilities remaining for the large-scale reconstruction of the country (Yazigi, 2020).
It should be noted here that broad-based sanctions should be differentiated from those targeted at individuals or entities. The role of sanctions (broad-based as opposed to targeted) and efforts to end broad sanctions that have negative consequences for civilians and reconstruction efforts must be studied and clarified (Omar Dahi, 2020).

In the midst of that, the Syrian regime has not been much affected, and that it is not interested in the social and economic status of the Syrians. Therefore, the worsening of economic misery is unlikely to change its calculations, as it should be noted that. Despite the heavy burden of sanctions on the regime's leadership and its aides, they are, in turn, offering them attractive opportunities to profit at the expense of the poor in the country. It is an opportunity that refutes the hypothesis that sanctions will affect the coherence and loyalty of the infrastructure of the regime. Otherwise, the continuation of these sanctions would be just a form of collective punishment that American policymakers must reconsider before a humanitarian catastrophe occurs (Qussai Jukhadar, 2020).

\subsection{The International Reactions}

While the European countries welcomed the sanctions imposed by the Caesar law, Russia, China and Iran showed their complete refusal of these sanctions, considering them unilateral and coercive sanctions that aim at complicating the situations in Syria after the regime is close to settling its battle against the extremist terrorist groups. It is a rejection that has been translated by many official statements and practical steps taken by these parties, which are allied to the Syrian regime.

Over the past nine years, Moscow and Beijing have spent billions of dollars in support of the Syrian regime, hoping for this support to benefit from post-war reconstruction projects, but the Caesar Act has destroyed all these expectations, especially in the short term, so Russia and China are demanding that the U.S. ease sanctions so that they can continue as intended, and they have addressed the United States in individual statements with the need to lift its "unilateral" and "coercive" measures against Syria. Zhang Jun, China's Permanent Representative to the United Nations, said: "The double standards adopted by the United States on humanitarian issues were revealed when the "Caesar Law" was imposed (Vohra, 2020). Jun adds: "as vulnerable countries like Syria struggle with the scourge of the Coronus virus, more sanctions are simply inhumane and could cause additional disasters " (Global China Daily, 2020).

In a statement dated June 17, 2020, the Russian Foreign Ministry confirmed that Moscow strongly opposes these sanctions, pointing out that "the Caesar Law, which aims at protecting 
civilians, works to harm only ordinary Syrians " (Ministry of the Foreign Affairs of Federal Russia, 2020). On this basis, Russia has taken practical steps toward securing reconstruction contracts with the Syrian Government, in outright defiance of the U.S., as the Syrian parliament has approved a series of deals with two Russian oil-mining companies from three major oilfields. Igor Matveev, former Head of the Russian Embassy's Trade and Economy Department in Damascus, said Russia was considering a $\$ 500$ million dollars project to redevelop the port of Tartus and build a \$200 million dollars fertilizer plant in Homs (Ramani, 2020).

The Iranian reactions were represented in the Iranian Foreign Ministry spokesman, Sayed Abbas Moussaoui, condemning the imposition of new U.S. sanctions under the so-called Caesar law, as a violation of the international law and human principles, Moussaoui indicated that: "While the scourge of the virus of Corona dominates the world, the imposition of such inhuman sanctions will only increase the suffering and pain of the Syrian people," he said. He also declared that this country would not give any credibility to such cruel and unilateral sanctions, which are passed and imposed on the basis of bullying, and considers them economic terrorism against the Syrian public and continuing embargoes, so that the ends his talk with his country's intention to continue economic cooperation with the State and the Syrian Government like the past, and working to strengthen economic relations with Syria despite the sanctions" (Ministry of Foreign Affairs, 2020)

Iran tries to protect the top regime in Syria for reasons related mainly to the sectarian dimension of the pro-Syrian government, as it has been working for many years to extend its influence in the Middle East, especially in Iraq, Lebanon, and Syria. Therefore, it may seem very logical that Iran rejects these sanctions, despite the damage it may cause, mostly as it also lives at the mercy of many of the previous sanctions related to its nuclear project.

The situation did not differ much; with regard to the reactions in Lebanon, where Hezbollah Secretary-General, Mr. Hassan Nasrallah, declared that this law is the last American weapon on Syria, and it confirms openly and definitely the victory of the Syrian regime in the military, security, political and even moral war. He also confirmed that Syria's allies who stood with it in its military conflict during the last years would not abandon it in the face of the economic war, although their circumstances are difficult (Hassan Nasrallah Speech, 2020).

\subsection{The Future of the Sanctions}

The scenarios of the future of the sanctions of the Caesar Civil Protection Act in Syria are subject to several indicators, primarily the humanitarian status and the futility or inability of sanctions to achieve their objectives for the long and medium terms, so this work will try to develop two different scenarios or to convey the contrasts:

\section{$>\quad$ The continuation of sanctions scenario}

Many reports expect that U.S. policy on Syria will become "more effective with the international community" after Joe Biden's arrival to the U.S. presidency, where a report published in the Middle East newspaper indicates that a Biden campaign consultant has informed some members of the Syrian community in America. His administration, in case of formation, will clarify to Russian President Vladimir Putin that there can be no U.S. or European support for Syria reconstruction in the absence of real political reform, and the consultant said that this reform should be meaningful and reliable movement regarding the main human issues and accountability. He stressed the need to release political prisoners while maintaining U.S. sanctions on the regime and its entities, including Russia (Al-Omari, 2020).

The United States Special Representative on Syria, Ambassador James Jeffrey, has said that his country punished about 75 individuals under the Caesar Act and other laws that it found to be more reasonable under certain circumstances, and according to Jeffrey, the current U.S. policy toward Syria will continue with bipartisan support, regardless of the winner of the U.S. election. "This is just the beginning of other waves of sanctions," he said at the end of the statement. Again, we start with the people closest to Assad because we believe it is imperative to focus on the accountability of those who financed him and those who enabled his military " (Al-Awsat, 2020).

Thus, the primary objective of sanctions from the American point of view is to bring down the Assad regime, as focusing on the people closest to its surroundings is evidence of trying to break down the elite cohesion of the administration, which is the point of strength through which it has continued to govern throughout the previous years of conflict. All the political regimes that have been buffeting the Arab Spring have not been able to withstand for more than four months at most in the face of waves of protest, while El- Assad regime has been able to confront the opposition, the street, and international sanctions with the help of the elitist cohesion of the power pyramid, and among the Alawite community, and because the United States is well-aware of the secret of this force, it is trying to continue sanctions, and to allocate an essential part of it to people closest to the President, in an attempt to break up that cohesion, which would then indicate the collapse of the regime. 
In this context, it should be noted that the United States legislator-in article 305 of the Act-has set a five-year period for the termination of its validity (Caesar Syria Civilian Protection Act of 2019). This means that the law is not open, so there may be no reason to reconsider its sanctions as long as the Syrian regime shows no real intention to make the required changes. Therefore, the scenario of continuity looks like the closest possible scenarios, especially at the moment.

\section{$>$ Depenalization scenario:}

The sanctions lifting scenario is subject to Article 301 of the lifting Index, where the article marked "sanctions Suspension" refers to the possibility of the President suspending the penalties in whole or in part for periods not exceeding 180 days if he considers that the following criteria have been met: (Caesar Syria Civilian Protection Act of 2019).

- $\quad$ The Syrian Government or the Russian Government cease using Syrian airspace to target the civilian population.

- The removal of isolation from areas besieged by the Syrian regime, Russia, Iran, or any other foreign person that prevents humanitarian access, freedom of movement, and medical care.

- $\quad$ Release of all political prisoners, allowing international human rights organizations to carry out appropriate investigations.

- Stop deliberate targeting by the Syrian regime, Russia, Iran, or any other foreign person of medical facilities, schools, residential areas, and places of civil assembly.

- $\quad$ The Syrian Government has taken severe steps to fulfil its obligations under the Convention on the Prohibition of the Development, Production, Stockpiling and Use of Chemical Weapons and on their destruction and to sign the Convention on the Prohibition of the Development, Production and Stockpiling of Biological and Toxin Weapons and on their defeat.

- The Syrian regime allowed the safe, voluntary, and dignified return of Syrians displaced by the conflict.

- The Syrian Government has taken serious steps to establish meaningful accountability for the perpetrators of war crimes in Syria and justice for the victims of such crimes.

The question of reinstatement of sanctions shall cease after the lifting of the sanctions in cases where the President determines that the standards described for lifting are no longer met (Caesar Syria Civilian Protection Act of 2019). which means that the Syrian regime, one of its Russian or Iranian partners, or any other foreign person found to be working with the administration has been suspended or sanctions have been lifted accordingly.

\section{Discussion}

This paper focused on trying to find a relationship between the stated reasons for the adoption by the United States of the Caesar Act, which is essential to protect Syrian civilians, and the consequences of the sanctions imposed by the law on civilians themselves, especially on the social and economic levels. The law contributes negatively to:

First: starving Syrian civilians, as it pushes them even more toward extreme poverty, most notably after the collapse of the Syrian Lira and the increase of prices, and the inability of many workers from the middle classes, which have become practically destitute, so there it has been a significant caste shift, according to which the middle class has disappeared, and society is divided between a wealthy class that enjoys all privileges and powers, which is a small, pro-regime class, and a vast type that includes the rest of the Syrian civilians, workers, merchants, artisans, etc. Second, the Act is also undermining Russia's reconstruction efforts, building on and promoting its projects among global companies. Everyone today has many concerns about the U.S. sanctions, so brokers who mediate between the Syrian regime and various foreign companies and institutions have become more active.

It is true that the paper did not deal much with the political consequences of the Act by focusing on the new political economy, which systematically imposes the economic implications of political events, and on the importance of the humanitarian threat that the Act poses to millions of Syrians who are stuck in their country, but this does not deny that there are many political consequences of the law. Especially on the level of elite cohesion within power in Syria - as it was notified before - which is one of the most dangerous consequences for Bashar AlAssad's regime that managed to resist change thanks to this important one, as targeting those close to El-Assad would represent a big blow to the authority on the far level. This is because the system symbols are isolated from their outer surroundings.

These results for researchers in the field of political sciences represent a theoretical entry for studying the political economy of the Syrian crisis. they are one of the most critical axes in learning the Syrian crisis or the current conflict in the Middle East, considering what the economic consequences represent in particular for the Syrian Ocean in Lebanon, Iran, and Turkey. The results for other disciplines, such as law and economics, provide input for understanding the Act's political nature. While allowing the public to read, follow, and be interested in Syrian affairs. 
Therefore, it will enable the non-political dimensions of political issues to be recognized.

\section{Conclusion}

This paper ultimately comes up with a set of objective findings that constitute a preliminary reading of the implications of the Caesar Civil Protection Act for the Syrian people, and it can summarize these findings according to the following points:

- The Caesar Civil Protection Act in Syria has contributed to a new economic reality in Syria and its geopolitical surroundings, especially after many economic agents have withdrawn from the scene for fear of U.S. sanctions, which has opened the door widely to the emergence of brokers and intermediaries.

- The new economic reality has led to a drop in the Syrian pound's price against the dollar and a rise in the price of consumer materials, which has contributed directly to increasing poverty rates in Syria.

- $\quad$ The closure of Lebanese banks against Syrian civilians has also contributed to a further decline in the price of the Syrian Lira, especially as these banks have been established for many decades, precisely after the Syrian crisis, their only external outlet in the world.

- The Caesar Act, which protects Syrian civilians in a negative and opposite way while trying to protect civilians from aerial bombardment, and the regime's indignation, is, in return contributing to their hunger, forcing them to live at the mercy of insufficient humanitarian aid.

- The Caesar Civilian Protection Act in Syria imposes severe penalties on the Syrian regime's pillars, targeting, to a greater extent, those close to power and decision-making centers to dismantle the elitist cohesion that has characterized the regime throughout the crisis years.

- All indications suggest that the sanctions in force in the Caesar Act will continue to be applied after John Biden's arrival to the U.S. presidency. The law was enacted with the Democrats and Republicans' approval in Congress, so that the lifting of sanctions seems a little distant, particularly when El- Assad regime does not respond to sanctions.

These preliminary findings are a result of Biography research. They need to be complemented by future studies, particularly at the specialty field level, so this paper will try to work in the future on another field of study, using appropriate methodological tools such as observation, observation of participation, interviews, and questionnaires.

\section{References}

1. Al Shami, I. (2020). The Syrian People and the Implications of Caesar's Law in the Siege of Assad. Retrieved from FIKRA FORUM: https://www.washingtoninstitute.org/fikraforum/view /syria-caesar-act-sanctions-assad

2. Al-Awsat, A. (2020). Washington Seeks to Eliminate PKK Presence in Syria, Says US Official. Retrieved from

https://english.aawsat.com/home/article/2607121/wa shington-seeks-eliminate-pkk-presence-syria-saysus-official

3. Al-Omari, M. (2020). Close to Biden: There is no reconstruction in Syria without political reform. Asharq Al-Awsat. Retrieved from: https://soo.gd/1N3B

4. Caesar Syria Civilian Protection Act of 2019. (2019, January 3). USA: Congress.

5. Caroline E. Brown, C. G. (2020). U.S. Government Issues First Designations under the Caesar Act as Part of Larger Set of Designations Targeting the Syrian Government. Washington: Crowell \& Moring.

6. Charles A. Sills, K. A.-K. (2020). Sanctioning Arabia through the Caesar Act: Economic Violence \& Imperial Anxieties in the "Middle East". Journal of Social and Political Sciences, 789-799.

7. Development, S. (2008). The Political Economy of Policy Reform: Issues and Implications for Policy Dialogue and Development Operations. Washington: The World Bank.

8. Global China Daily. (2020). Damascus hits out at new sanctions by Washington. Retrieved from https://www.chinadaily.com.cn/a/202006/19/WS5eec 198ea3108348172541d3.html

9. Grindle, M. S. (1989). The New Political Economy : Positive Economics and Negative Politics. Washington : The World Bank.

10. Hassan Nasrallah Speech. (2020). Youtube. Retrieved from:

https://www.youtube.com/watch?v=i53LcRn1Es8

11. Heydemann, S. (2020). The Caesar Act and a pathway out of conflict in Syria. Brookings. Retrieved from: https://www.brookings.edu/blog/order-fromchaos/2020/06/19/the-caesar-act-and-a-pathway-outof-conflict-in-syria/

12. Ministry of Foreign Affairs. (2020). Foreign Ministry Condemns US Sanctions on Syria. Retrieved from http://irangov.ir/detail/341232

13. Ministry of the Foreign Affairs of Federal Russia. (2020). Press release on anti-Syria Caesar Act. 
https://www.mid.ru/en/foreign_policy/news/-

/asset_publisher/cKNonkJE02Bw/content/id/416800 2

14. Nasr, R. (Director). (2020). Rabie and 'Aref Interview on CNBC [Motion Picture].

15. Omar Dahi, R. N. (2020). Conflict Economies in Syria: Roots, Dynamics, and Pathways for Change. Beirut: Syrian Center for Policy Research.

16. Pompeo, M. R. (2020). Syria Caesar Act Designations. U. S. DEPARTMENT of STATE. Retrieved from: https://www.state.gov/syria-caesaract-designations/

17. Qussai Jukhadar, E. T. (2020). Caesar Act: The Syrian people are sapped while Assad grows stronger. Retrieved from: https://www.atlanticcouncil.org/blogs/menasource/ca esar-act-the-syrian-people-are-sapped-while-assadgrows-stronger

18. Ramani, S. (2020). How are Russia and China responding to the Caesar Act?. Middle East Institute. Retrieved from: https://www.mei.edu/publications/how-are-russiaand-china-responding-caesar-act

19. SJAC. (2020). Sanctions, the Caesar Act, and COVID-19 in Syria : Policy Analysis and Recommendations. Washington: Syria Justice and Accountability Centre (SJAC).

20. Vohra, A. (2020). Block Aid: Russia and China's Response to the Caesar Act. Retrieved from inside arabia: https://insidearabia.com/block-aid-russia-andchinas-response-to-the-caesar-act/

21. Yazigi, J. (2020). Syria's Growing Economic Woes: Lebanon's Crisis, the Caesar Act and Now the Coronavirus. Arab Reform Initiative. 